\title{
Natural Resource Potential of the World Economy under Globalization
}

\author{
Ainur O. Ongdash ${ }^{1}$, Ernur Ongdashuly ${ }^{2}$, Bagdat Amandosuly ${ }^{3}$, \\ Yermek S. Chukubayev ${ }^{4}$, Gulnara R. Useynova ${ }^{5}$, Karlygash R. Useinova ${ }^{6}$, \\ Gulmira O. Altaeva ${ }^{7}$, Gulnar M. Imasheva ${ }^{8}$ and Gulfira I. Zholdasova ${ }^{9}$
}

${ }^{1} \mathrm{PhD}$ doctor, associate professor of Chair of International Relations and World Economy of Department of International Relations, Al-Farabi Kazakh National University, Almaty, Kazakhstan.

${ }^{2}$ Master's degree of Jurisprudence, Teacher of Chair "Sate and Law Theory and History, Constitutional and admistrative law" of faculty of law, Al-Farabi Kazakh National, University, Almaty, Kazakhstan.

${ }^{3}$ Student of PhD, senior lecturer of Chair of International law of Department of International Relations, Al-Farabi Kazakh National University, Almaty, Kazakhstan.

${ }^{4}$ Candidate's degree in Historical Sciences, associate professor of Chair of International Relations and World Economy of Department of International Relations, Al-Farabi Kazakh National University, Almaty, Kazakhstan

${ }^{5}$ Doctor in jurisprudence sciences, Professor of chair "Sate and law theory and history, constitutional and admistrative law" of faculty of law, Al-Farabi Kazakh National University, Almaty, Kazakhstan

${ }^{6}$ Candidate's degree in jurisprudence sciences, Associate professor of chair "Sate and law theory and History, constitutional and admistrative law" of faculty of law, Al-Farabi Kazakh National University. Almaty, Kazakhstan

${ }^{7}$ Student of PhD, Vice-rector of the Academy of Civil Aviation, Almaty, Kazakhstan ${ }^{8}$ Doctor of Technical Sciences, Associate Professor of the Academy of Civil Aviation, Almaty, Kazakhstan ${ }^{9}$ Master's degree of Economics, senior lecturer of the Academy of Civil Aviation, Almaty, Kazakhstan

DOI: http://dx.doi.org/10.13005/bbra/1949

(Received: 15 August 2015; accepted: 18 October 2015)

The article deals with the essence of "natural resource potential" and "natural resources" concepts. The main tendencies in the strategy of the economic growth of the world economy are revealed. Ways for the world economy development are offered basing on the natural resource potential preservation. The "green economy" concept directly relating to effective use of natural resources is considered.

Key words: Natural resource potential, natural resources, natural capital, globalization, "green economy".

Various approaches to the definition of the "natural resource potential" and "natural resources" concepts are observed in the scientific literature. The total productivity of natural resources and conditions of the complex society needs satisfaction (environmental, social, economic, recreational, cultural) is comprehended as the natural resource potential.

\footnotetext{
* To whom all correspondence should be addressed. Mob.: 87012284808,

E-mail: ainukon84@mail.ru
}

The natural resource potential is judged mainly by the nature diversity, quantitative and qualitative composition and availability of natural resources, environment quality compliance with accepted standards and norms.

Natural resources represent natural components and nature forces, which are used or can be used as means of production and consumption goods to meet the society's material and mental needs, to improve the quality of people's life. Actually resources are understood as energy, matter, information which is an initial source for 
functioning, development, existence of a specific system. Use of natural resources leads to their transformation into the nature productive forces, directly related to the social production efficiency, and is the potential for the further social development. The natural resources are considered as a part of the geographical environment by its material essence. According to A.A. Mintz, natural resources are "natural bodies and forces, which can be used at this level of the productive forces development and of the study to meet the human society's needs as participation in the physical activity" .

M.F. Reimers notes that natural resources are nature objects and events, used currently and in future for direct and indirect consumption, help in creation of material wealth, in reproduction of human resources, in maintenance of human existence conditions, in improvement of life quality, including nature phenomena. The "natural resources" category refers to a direct connection of the nature with human activities, often resulting in negative social phenomena, causing great harm to nature ${ }^{9}$.

The classification of natural resources by V. Polterovich, V. Popov and A. Tonis ${ }^{8}$ are of interest as well as the determination of characteristics of concentrated natural resources (such as oil, gas, since most exported goods).

According to V. Polterovich, V. Popov and A. Tonis, the natural resources can be divided into two types: point (oil, gas, coal, minerals) and diffuse (forest, fish, water, land) ${ }^{8}$. J. Isham, M. Woolñoñk, L. Pritñhett and G. Busby distinguish point resources among natural resources, which are extracted from a narrowed geographic or economic base (oil and gas), crop plantation (cocoa, bananas) and diffuse natural resources extracted from a wider geographical or economic basis ${ }^{15}$.

The most significant features of the point natural resources according the classification by V. Polterovich, V. Popov and A. Tonis are shown in Fig. 1.

V. Polterovich, V. Popov and A. Tonis note that these features of point natural resources as commodities determine the specifics of their markets $^{8}: 1$ ) oligopolistic market - concentration of few large companies; 2) active participation of the state in the natural resource production and trade; 3) High efficiency of resource exploration industries contribute to the mining sector be more attractive for investment and human resources compared to the non-resource sectors; 4) the market insufficiency, which mostly caused by poor creation of strong externalities at investment and human resources for other industries, insignificantly affect the increment of employees' new knowledge and professional development; 5) simplicity of the technology used in the mining industry, combined with high profitability of the export, reduce the effectiveness of foreign capital attracting; 6) risk of nationalization. The sharp rise in raw materials price worldwide led to more independent behavior of countries rich in natural resources, which are tightening conditions for foreign investors' access to the resource stock by changing investment terms, explaining by unfair share of the profits obtained. As a result, the hydrocarbon production is increasingly controlled by nationalized giants.

The value of natural resource potential is an element of the national wealth and can be quantitatively represented only through cost parameters in the so-called national cadastral or world prices. Typically, the natural resource potential is quantitatively characterized as the amount of values of basic types of the natural resources.

The composition and the ratio of the main types of natural resources in the natural resource potential is its component structure. The potential functional structure means the composition and the ratio of the main types of natural resources in their participation in the territorial labor division.

The territorial structure of the natural resource potential is principal forms and types of the territorial spread or concentration of natural resources and is an important concept to determine the maximum amount of natural resources that can be used harmlessly for the existence and development of nature systems and human.

The "natural resource potential" concept is closely related to the "natural capital" concept. The ratio of these concepts is actively discussed in the literature.

I.P. Derevyago understands the natural capital as a set of natural resources, which may contribute to the national wealth increase over a long period of time, and objectively required for reproduction ${ }^{3}$. 
S.K. Harichkov considers the natural capital as a set of natural resources which are used or can be used in the production of goods. In his opinion, the natural capital is a stock of assets of the natural environment, providing a flow of valuable goods and services in future. This flow is "natural income", and what provides it - "natural capital"11.

The natural capital is described most significantly as a source of actual flow of natural resources by R. Costanza, H. Daly ${ }^{13}$. This term

Table 1. Main Natural Resources for the Economic Systems, 2012

\begin{tabular}{|c|c|c|c|}
\hline \multirow[t]{2}{*}{ Region/Country } & \multicolumn{3}{|c|}{ Resource / Characteristics } \\
\hline & Reserves,\% & World Share, \% & Procurement, years \\
\hline \multicolumn{4}{|l|}{ Oil, mln tons } \\
\hline Europe & 2455,4 & 1,3 & 9 \\
\hline Russia & 14920,0 & 7,7 & 32 \\
\hline Asia & 115316 & 59,8 & 83 \\
\hline Africa & 15417,4 & 8,0 & 35 \\
\hline America & 44108,9 & 22,9 & 48 \\
\hline Australia and Oceania & 513,6 & 0,3 & 21 \\
\hline \multicolumn{4}{|l|}{ Natural gas, billion $\mathrm{m}^{3}$} \\
\hline Europe & 6458,1 & 3,7 & 68 \\
\hline Russia & 47544,0 & 27,4 & 73 \\
\hline Asia & 86944,1 & 50,1 & 54 \\
\hline Africa & 14085,3 & 8,1 & 62 \\
\hline America & 14577,3 & 8,4 & 75 \\
\hline \multirow[t]{3}{*}{ Australia and Oceania } & 4066,8 & 2,3 & 56 \\
\hline & \multicolumn{3}{|c|}{ Coal (all types), mln tons } \\
\hline & $\begin{array}{l}\text { Reserves } \\
\text { in place }\end{array}$ & $\begin{array}{l}\text { Confirmed reserves, } \\
\text { to be extracted }\end{array}$ & $\begin{array}{l}\text { World Share in } \\
\text { mineral resources, \% }\end{array}$ \\
\hline Europe & 591093 & 91825 & 13,6 \\
\hline Russia & 271757 & 193771 & 6,3 \\
\hline Asia & 1451146 & 266887 & 33,4 \\
\hline Africa & 109868 & 55093 & 2,5 \\
\hline America & 1225937 & 317347 & 28,2 \\
\hline Australia and Oceania & 690833 & 97873 & 16,0 \\
\hline
\end{tabular}

Source: [4].

Table 2. Forecast indicators of the economy development under the traditional and "green" scenarios

\begin{tabular}{|c|c|c|c|c|c|}
\hline \multirow[t]{2}{*}{ Indicator } & \multirow{2}{*}{$\begin{array}{c}2011 \\
\text { Evaluation }\end{array}$} & \multicolumn{2}{|c|}{2030} & \multicolumn{2}{|c|}{2050} \\
\hline & & $\begin{array}{l}\text { Traditional } \\
\text { scenario }\end{array}$ & $\begin{array}{c}\text { “Green” } \\
\text { scenario, \% }\end{array}$ & $\begin{array}{l}\text { Traditional } \\
\text { scenario }\end{array}$ & $\begin{array}{r}\text { "Green" } \\
\text { scenario, \% }\end{array}$ \\
\hline GDP (USD trillion) & 69344 & 119307 & 2,7 & 172049 & 15,7 \\
\hline GDP per capita (USD) & 9992 & 14577 & 2,4 & 19476 & 13,9 \\
\hline Total employment (mln people) & 3187 & 4204 & $-1,5$ & 4836 & 0,6 \\
\hline Forest area (bln Ha) & 3,94 & 3,83 & 7,9 & 3,71 & 21,0 \\
\hline Water demand ( $\mathrm{km}^{3}$ /year) & 4864 & 678 & $-13,2$ & 8434 & $-21,6$ \\
\hline Emission to biological capacity ratio & 1,51 & 1,84 & $-21,5$ & 2,23 & $-47,9$ \\
\hline $\begin{array}{l}\text { Primary energy demand } \\
\text { (mln t oil equivalent / year) }\end{array}$ & 12549 & 17755 & $-19,6$ & 21687 & $-39,8$ \\
\hline
\end{tabular}

Source: [6]. 
covers both a set of natural resources and the environment. Components of the natural capital are:

a) non-renewable natural capital (nonrenewable energy resources);

b) renewable or cyclically used natural capital (non-energy mineral resources);

c) renewable and potentially renewable natural capital (environment in general).

M.A. Nevskaya and V.L. Trushevsky believe that the "natural resource potential" category should be understood wider than the "natural capital". They define the latter as natural resources with the established right and involved into the economic circulation (Fig. 2) ${ }^{7}$.
Fast economic growth in developed economies in the second half of the twentieth century and in "young” economies in China, India, Brazil and South-East Asia, at the end of the XX century - at the beginning of the XXI century, caused mostly by the involvement of significant natural resources into the national economy to increase the industrial production rate.

The dominated raw material resource tendencies in the strategies of the economic growth (especially developing countries) result in significant reduction of natural resources. Restriction (deficit) of resources for many economies (Table. 1) and strict competition lead to changes in economic rules and global competition.

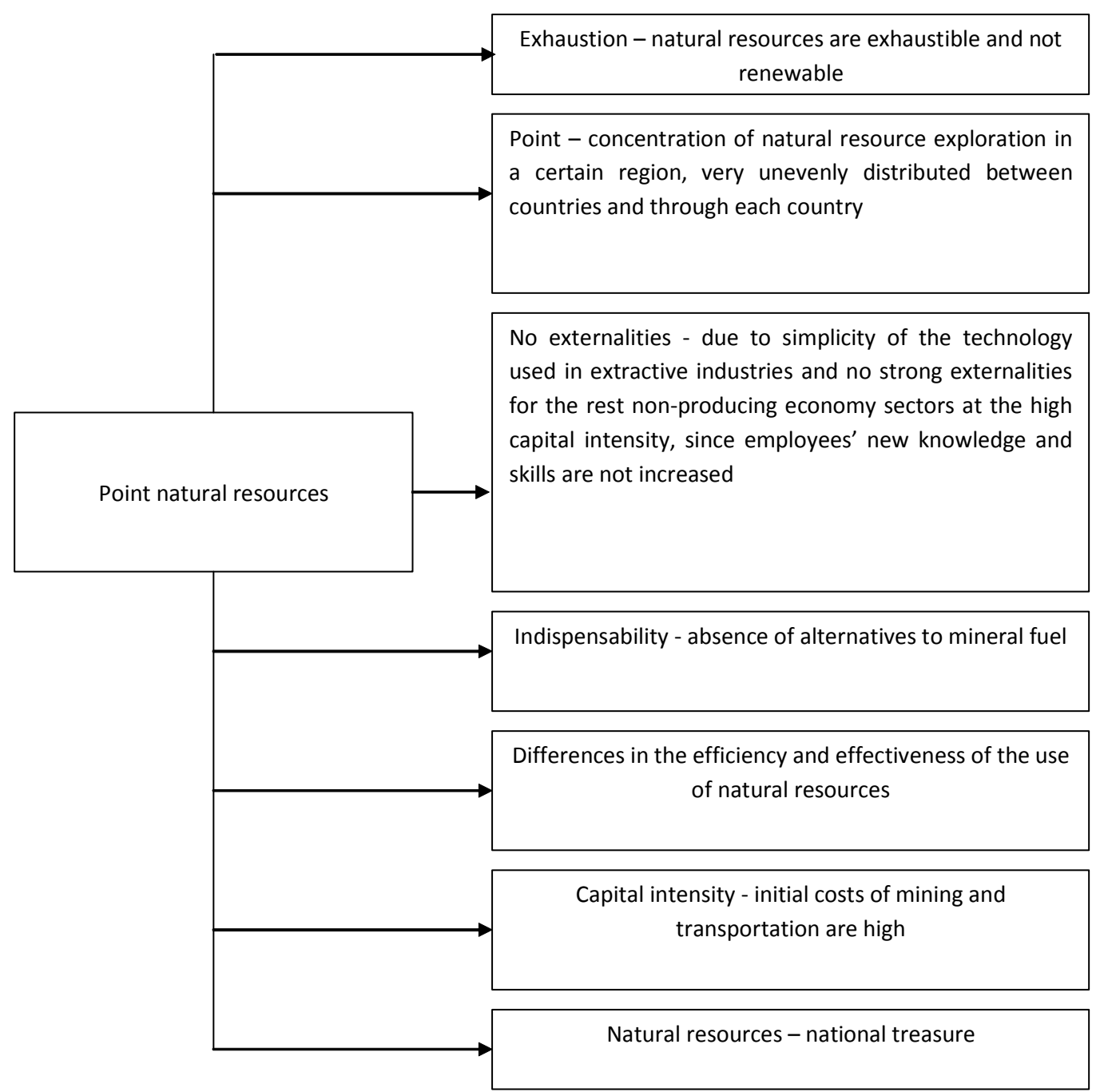

Fig. 1. Features of point natural resources Source: designed by the Author [8] 
Global competition in this century is first of all a struggle between countries for limited resources, especially, natural ones. Under rising global competition, resource costs, significant price uncertainty, the question arises about the strategy development for resource procurement in countries searching for permanent increase of efficiency and productivity.

The world economy has passed the stage when the natural resources were key factors. The crisis spreading through the whole planet confirms the need to find ways for the further development, based on the preservation of natural resource potential.
The concept of sustainable development was accepted at UN Conference on Environment and Development in 1992. The main idea of this concept is to ensure the social and economic development, which will maintain and expand opportunities currently available without any harm for future generations. The process of searching for an effective model to implement this concept accelerated due to the recent economic crisis and returned the researchers to "green economy". According to M. Kennet, only "green economy" is able to stabilize the economic system and to balance the human's interests, nature and efficient use of resources ${ }^{16}$.

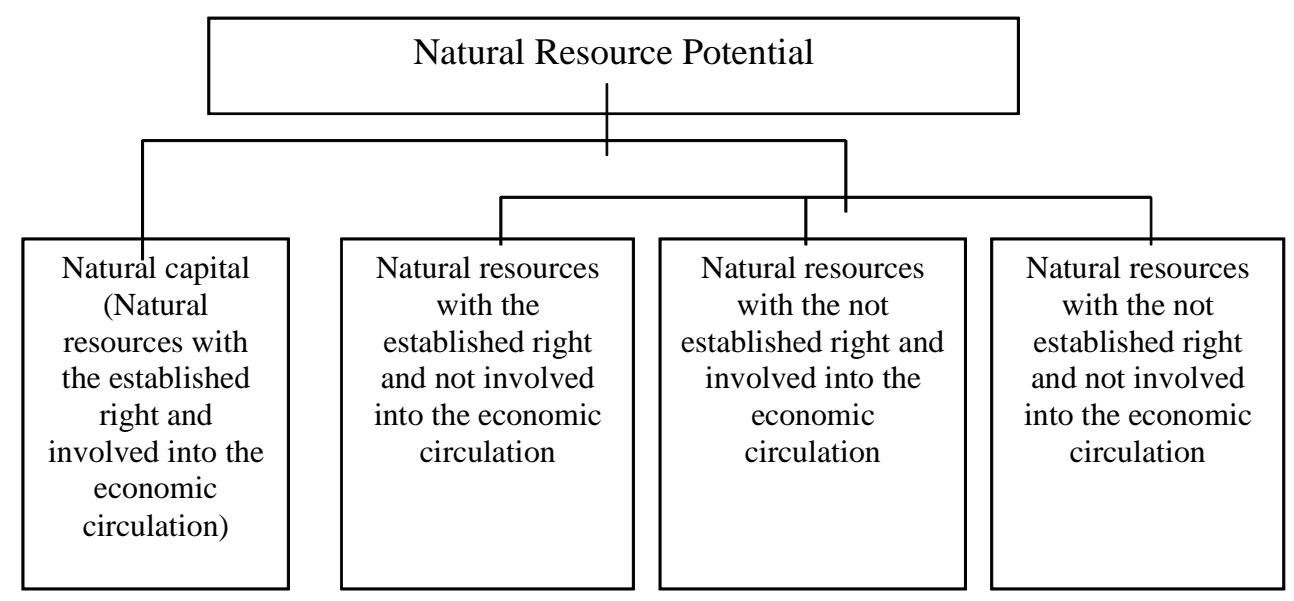

Fig. 2. The natural resource potential structure

The "green economy" term was first used in the "Green Economy Project" paper ${ }^{18}$, which is a software text for supporters of this new discipline, focused upon the sustainable development economy.

Since the United Nations started the Green Economy Initiative (GEI) in 2008, this concept is constantly discussed being a subject of plenty of definitions and interpretations. Besides, other terms such as "green growth" or "economy greening" have been recently spread. These terms are interchangeably used for a wide range of industries, for example energy or natural resource management.

UN characterizes the "green economy" as an economy providing the population welfare and reducing environmental risks. General characteristics of "green" economy are as follows: effective and efficient use of natural resources, reduction of greenhouse gas emissions and implementation of new, "green” technologies².

General principles of the "green economy” are stipulated in UNEP documents (eg, "UNEP Global Green New Deal") where the definition is offered: the green economy is an economic activity, "one that results in improved human well-being and social equity, while significantly reducing environmental risks and ecological scarcities” ${ }^{10}$.

The "green economy" policy is officially adopted by the OECD in 2009 as the strategic direction ("OECD Green Growth Strategy") ${ }^{17}$. "Roadmap to Resource Efficient Europe" and "Green Economy Strategy" are official documents in this field in Europe. "Roadmap for moving to a low carbon economy” is adopted for Asian and 
Pacific Region ${ }^{14}$. The Russian model of "green economy" is present in the "2020 Strategy" report, the Concept for moving to a "green economy" is developed in Kazakhstan ${ }^{12}$.

According to UNEP experts, a "green" scenario for the global economy development (providing for annual investment into the technologies of about 1.3 trillion dollars) may ensure exceeding of the total actual GDP by $16 \%$ and per capita GDP - by $14 \%$ and reduction of the world economy demand in energy by $48 \%$ by 2050 compared to the baseline scenario ${ }^{6}$.

Forecast indicators of investment of additional 2\% of GDP for the "green economy" development in comparison with the results of their contribution into the ordinary scenario are presented in Table. 2.

The concept of efficient use of natural resources is directly related to the green economy concept, since moving to a "green economy" depends on the solution of two related tasks to maintain the ecosystem structure and functions (ecosystem stability) and to reveal the ways for reduction of resources use in the production and consumption, and for reduction of their impact on the environment (resource efficiency).

According to N.V. Bagrov, the main difference between the "green economy" from previous economic theories is the "natural capital" involved into the market process and its consideration as self-generating sector of the economy. "Green economy" transforms relations with natural resources, makes to review the fundamental issues of the nature and society relationship, a look at the man's role in the world, at his place in the nature, which vary depending on the regional specificity, provides the economic progress and political stability by the nature involvement into the capital and productive force structure ${ }^{1}$.

Thus, the "green economy" model has arisen in answer to modern challenges, related to the natural capital degradation. According to UNEP, there is no universal solution for moving to a "green economy." All activities should be linked to characteristics and the natural heritage in each country, to a level of its development, the effective function of its institutions, as well as the type and extent of the market mechanism defects, priority sectors, targets and other factors specific to the particular situation.

\section{REFERENCES}

1. N.V. Bagrov. Natural capital - the basis of the regional economy // Culture of the Black Sea region population. 2001; 21: 235 - 238.

2. S. Bobilev, V. Zakharov. "Green” economy and modernization. Environmental and economic principles of the sustainable development. Bulletin of the Institute for Sustainable Development of the Public Chamber of the Russian Federation No. 60. 2012.

3. I.P. Derevyago. Analysis of the reproductive processes in the system of sustainable development // Problems of Modern Economics, 2008; 2: 26.

4. $\quad$ Mineral resources of the world. - M., 2012.

5. A.A. Mints. Economic evaluation of natural resources. - M.: Thought, 1972; 302.

6. Meeting "green economy": Ways to the stable development and eradication of poverty Summary report for the authorities' representatives. France, Saint-Martin-Bellevue, UNEP, 2011 // http://www.un.org/ru/ development/sustainable/ger_synthesis.pdf

7. M.A. Neva, V.L. Trushevsky. Modern scientific approaches to the study of the natural resource potential // Collection of scientific papers "Problems of the system modernization of the Russian economy: social, political, financial, economic and environmental aspects." SPb.: Non State Higher Educational Institute of Business and Law - 2010; 9: 438-443.

8. V. Polterovich, V. Popov, A. Tonis. Economic policy, institution quality, and mechanisms of the "resource curse" // Report at the VIII International scientific conference.

9. M.F. Reimers. Ecology: theory, law, rules, principles and hypotheses. - G.: Publishing House "Young Russia”, 1994; 367 pg.

10. The Russian National Committee for the UN Environment Program. Global Green New Deal. Report // UNEP 2009.

11. S.K. Harichkov. Natural capital as a factor for the stable development // Nowoczesnosc ponowoczesnosc. Spoleczenstwo obywatelskie w europie srodkowej I wschodniej. Lublin. KUL. 2007; 2: 421- 425.

12. The energy of unity. "Green" economy: global trend of the development // KAZENERGY. 2013; 2 (57).

13. Costanza R., Daly H.E. Natural Capital and Sustainable Development Conservation Biology, 1992; 6(1): 37-46.

14. European Commssion. Europe 2020: a European strategy for smart, sustainable and inclusive 
growth. Brussels, COM (2010) 2020.

15. Isham J., Woolcock M., Pritchett L. and Busby G. The Varieties of Resource Experience: Natural Resource Export Structures Affect and the Political Economy of Economic Growth. The World Bank Economic Review, 2005; 19(2): 141 -174 .

16. Kennet M. What Green Economics? An age of global transformation - An Age of Green
Economics // www.greeneconomics.org.uk

17. Organization for economic co-operation and development Declaration on Green Growth, adopted at the Meeting of the Council at Ministerial Level on 25 June 2009.

18. Pearce D.W., Markandya A. and Barbier E.B. Blueprint for a Green Economy. Earthscan Publications, London, 1989. 